\title{
Examining Learning Approaches among Trainee Teachers and Its Relationship with Academic Achievement
}

\author{
Norshidah Nordin, Rohaya Abdul Wahab, Nadia Ainuddin Dahan \\ Universiti Teknologi MARA, 40450 Shah Alam, Selangor, Malaysia \\ Shidah147@gmail.com
}

\begin{abstract}
Studies reported that there were deficiencies in educational outcomes among students in terms of their critical thinking, communication, and problem-solving skills. These deficiencies were due to students' learning approaches that affect their ability to think critically and thus decrease academic performance. Hence, this study intends to examine the learning approaches used by the trainee teachers of UiTM; and whether these approaches could enhance their academic performance. A total of 255 respondents participated in this study. The result also evidence that there was positive but low relationship between deep and strategic approaches to learning on academic performance. This finding has practical implications for educators in developing a more systematic approach to academic teaching and learning.
\end{abstract}

Keywords: deep approaches, surface approaches, strategic approaches, productive learning

eISSN 2398-4295 @ 2018. The Authors. Published for AMER ABRA cE-Bs by e-International Publishing House, Ltd., UK. This is an open-access article under the CC BY-NC-ND license (http://creativecommons.org/licenses/bync-nd/4.0/). Peer-review under responsibility of AMER (Association of Malaysian Environment-Behaviour Researchers), ABRA (Association of Behavioural Researchers on Asians) and CE-Bs (Centre for EnvironmentBehaviour Studies), Faculty of Architecture, Planning \& Surveying, Universiti Teknologi MARA, Malaysia.

http://dx.doi.org/10.21834/ajbes.v3i11.104 


\subsection{Introduction}

Malaysian universities nowadays aspire to produce graduates who are knowledgeable and equipped with soft skills which include higher order thinking skills. One of the ways to enhance higher order thinking is through promoting deep approaches to learning. Studies evidence that students who engaged in deep-level learning were more intrinsically motivated to seek meaning from their learning. In fact, they were committed to learning where they related subject material to meaningful contexts and prior knowledge, thus, enhance higher thinking order. On the other hand, students who adopted a surface approach based their learning on extrinsic motivation of positive and negative reinforcement. Consequently, studies reported that there were deficiencies in educational outcomes among undergraduate as well as post graduate students in terms of critical thinking, communication and problem solving skills. The overriding question is, were these deficiencies due to learning approaches that affect their ability to think critically. Furthermore, to what extends educators have played their roles in helping post graduate students, particularly among trainee teachers to increase positive learning outcomes.

\subsection{Literature Review}

Students' approaches to learning are expanding line of studies that focused on describing and assessing students' learning process ( Entwistle et. al, 2001). There were extensive research in characterizing students' approaches to learning ( Ausbel, 1968, Wittrock, 1974), Marton and Saljo, 1976, ). For example, earlier work of Ausbel (1968) used the terms as meaningful and rote learning. Nevertheless, Wittrock (1974) described learning approaches as generative and reproductive processing. However, it was Marton and Saljo (1976) who coined the concept the learning approaches into two categories as surface and Deep approach. In fact, it becomes one of the most influential concepts to have emerged from research into teaching and learning in higher educational (Dale and Mc Carthy, 2006). The proponents of approaches to learning such as Biggs (1987), Entwistle (1987), Richardson (1994a) and Marton and Saljo (1976) assert that the important aspect of the distinction between the two approaches lies in the intention or the absence of intention to understand. Therefore, the basic distinction in approaches to learning is students who applied a deep approach to learning aim towards the fundamental idea, meaning in the materials they were studying and critically relating it to other experience and ideas, which were associated with an intention to understand. Thus in order to do this, they will processes the materials actively. Biggs (2003) suggests that students who deploy a deep approach tend to be intrinsically motivated, derived enjoyment from the learning task and apply the acquired knowledge to the real world. On the other hand, students applying surface approach tend to be extrinsically motivated by minimizing the use of their intellectual capacity, avoid personal understanding and sought to remember the text by word in a test or exam rather than actually understanding it. In this sense, Marton and Saljo (1976) argue that students adopting surface level of processing, direct their attention to the text itself so employed a reproductive orientation. 
Conversely, Russel (2004) in his study, examining the nature of learning and the course and the teaching preference among university students had a rather similar finding to many researches done earlier on tertiary students. His study focused more by examining what has been categorized as 'surface' versus 'deep' approach in learning. The findings indicated that most of the students supported for preference to have structure and support in their learning that relates to surface learning though for another task, deep learning outcomes too were slightly evident in the outcome of the task. This indication of preference for surface outcome denotes the importance of learning for the students, relating to an immediate need to understand what was expected and desired from the learning task. Russel too further concluded that in deep learning, besides the nature of the learning tasks, factors like course expectations and the teaching/learning strategies used in the course too would influence students in their perceived beliefs on learning.

\section{Approaches to learning and gender}

Previous studies showed that males and females learn differently from each other (Ebel, 1999). For example, a Meta analysis study done by Severiens and Dam (1994) show that man showed a greater preference than women for the abstract conceptualisation mode of learning. Besides, men were more often interested in the courses for the qualifications they offer while women are more often interested in learning for learning's sake. In another study done by Dorval (2000) suggest that the language learning tasks connected with problemsolving, male students and female ones show clear differences in their approaches to learning tasks (Dorval, 2000). In this sense, students-males produced mass of short spurts of speech. On the other hands, students-females produced big blocks of talk, they were obedient, and there was much attentive listening and sympathizing. Dorval (2000) further explain that male students prefer learning tasks connected with competitions in hierarchical groups, while female students learn by collaboration in small groups in which mutual liking is important. Hassan and Joyce (2001) found that males scored higher on surface learning than from their female counterparts, while Arquero Montano at al (2010) found vice versa.

\section{Approaches to learning and academic achievement}

Cano (2007) revealed that both intelligence and approaches to learning are significant factors in predicting students' academic achievement. Cano's (2007) research found that high usage of deep approach to learning with general intelligence will resulted in a better academic performance. This is because students with successful academic achievement are more prone to utilize a deep approach to learning than those who are less successful (Zeegers, 2001, cited in Ali and Sebai, 2010). In addition, Entwistle, Tait, \& McCune, (2000) stated that in the subsequent years of a degree course especially when the evaluation system directly rewards a display of conceptual understanding, students will demonstrate high scores on the deep approach which will relate to academic success. Byrne et al. (2002), Duff (2004) and Tan and Choo (1990) cited in Ballantine et al., (2008), all stated that students who adopt desirable learning approaches, especially by scoring higher on deep approach and strategic approach scales, achieve high level of academic success. Other studies also corroborate the 
conclusions that deep and strategic approaches to learning tend to be correlated with academic accomplishment (Cano 2005, Watkins 2001, cited in Lietz \& Matthews, 2006). Unfortunately, not all results show a significant relationship between a deep approach to learning and the quantitative scores of the learning outcome (Byrne, Flood, \& Willis, 2004; Gijbels et al., 2005; Kember et al., 1995). Some studies found that deep approach did not result in higher grades on the evaluation (Minbashian et al., 2004; Trigwell \& Prosser, 1991). Trigwell and Prosser (1991) cited in Kyndt (2011) studied the relationship between the observed approaches to learning and the academic achievement of 122 first-year students in a nursing course. They found a positive correlation between a deep approach to learning and high qualitative levels in the academic achievement, however they found no such correlation to quantitative differences in outcome. In this respect, Dochy (2005) pointed out the fact that a deep approach to learning was rarely rewarded by the evaluation system. The reason therefore may be that the evaluation mainly assesses knowledge for which the use of a surface approach suffices to be successful (Scouller, 1998). Nevertheless, many studies have explored approaches to learning in school context. In the higher educational settings, students face different conditions that may affect their learning. Thus, understanding trainee teachers' approaches to learning is important to improve learning in higher educational settings. Besides, in order to empower education students to assume responsibility for creating a sustainable future, these students should be at the centre of a forward looking academic learning atmosphere. Furthermore, with the significant expectations placed on teacher education programmes by the Malaysian government, how do education students experience the teaching and learning approaches at their university? Hence, this study intends to examine the learning approaches used by the trainee teachers of UiTM; and whether these approaches could influence their academic performance and gender.

\subsection{Methodology}

This study utilized a survey method and descriptive in nature. A self report questionnaire was used to gather information related to the objectives of the study. The items measuring approaches to learning was adapted from Entwistle et al.'s (2000) with modification to suit the purpose of the study. The instrument consists of three components which are deep approach, surface approach, and strategic approach and 13 sub-scales. The respondents are asked to indicate their degree of agreement with the statements, scored on a seven-point Likert-type scale ( $1=$ Strongly Disagree; $7=$ Strongly Agree). The reliability of coefficient of the scale was found to be 0.952 . About 314 trainee teachers were asked to complete the questionnaire. 255 of them responded and returned the completed questionnaire. Hence the response rate was $81.2 \%$. This trainee teachers consist of $10.9 \%$ males and $89.1 \%$ females undergraduates from various fields and currently undertaken a post graduate diploma program at the faculty of Education UiTM, Shah Alam. The mean age of the trainee teachers was 28 years old. . Pearson's Product -Moment Correlation Coefficient (r) was used to measure the strength and direction of the relationship between approaches to learning and 
academic performance. In order to identify the contribution of each significant independent variable towards the variance of academic performance, multiple regression was utilized

\subsection{Results and Discussions}

\section{Research objective 1: an analysis on the approaches to learning used by trainee teachers of UiTM, Shah Alam}

Table 1: Learning approaches used by trainee teachers

\begin{tabular}{lll} 
Approaches to learning & Mean & Std deviation \\
\hline Deep approach & 5.0380 & 0.67043 \\
Strategic approach & 5.1325 & 0.71551 \\
Surface approach & 4.3224 & 0.76349 \\
\hline
\end{tabular}

Mean indicators $1-2.99=$ low; $3.00-4.99=$ moderate; $5.00-7.00=$ high

Table 4.0 shows the mean scores of approaches to learning used by trainee teachers of UiTM, Shah Alam. The results indicated that the respondents used both deep and strategic approaches to leaning where mean scores were 5.1325 and std deviation= .71551 and 5.0380 , std dev= .67043 respectively, as compared surface approaches to learning $(\mathrm{m}=4.4224$, std dev= .76349). This finding is in line with the study done by Hanin Naziha Hasnor, Zaiton Ahmad and Norshidah Nordin (2013)

Table 2: Dimensions in approaches of learning used by trainee teachers

\begin{tabular}{lcc} 
Approaches to learning & Mean & Std deviation \\
\hline Deep approach & & \\
Seeking meaning & 5.0675 & .78570 \\
Relating ideas & 4.9615 & .69503 \\
Use of evidence & 5.0372 & .75258 \\
Interest in ideas & 5.1081 & .80206 \\
& & \\
Strategic approach & & \\
Organized studying & 5.0266 & .77795 \\
Time management & 5.0201 & .82178 \\
Alertness to assessment demands & 5.2835 & .82775 \\
Achieving & 5.2059 & .77768 \\
Monitoring effectiveness & 5.1307 & .78995 \\
& & \\
Surface approach & & 1.086 \\
Lack of purpose & 3.8615 & .91140 \\
Unrelated memorizing & 4.2206 & .81178 \\
Syllabus -boundness & 4.6635 & .89628 \\
Fear of failure & 4.5230 & \\
\hline
\end{tabular}

Mean indicators 1-2.99= low; 3.00-4.99= moderate; $5.00-7.00=$ high 
Table 4.1, presents the data on further descriptive analysis of the learning approaches used by the trainee teachers. The finding reveals that sub scales of strategic approaches shows high mean scores namely Alertness to Assessment Demands $(m=5.2835$, std $=0.82775)$, Achieving ( $m=5.2059$, std $=0.77768)$, Monitoring Effectiveness $(m=5.1307$, std $=0.78995)$, Organised Studying $(m=5.0266$, std $=0.77795)$ and Time Management $(m=5.0201$, std $=$ .82178). The result also indicated that the four sub-scales of deep approaches shows high mean scores namely Seeking Meaning $(m=5.0675$, $t s d=0.78570)$, and Interest in Ideas $(m=5.1081, s t d=0.80206)$ and use of evidence $(m=5.0372, s t d=0.75258)$. However, relating ideas shows a moderate mean scores $(m=4.9615$, std $=0.695030)$. On the other hands, all the sub scales of surface approaches show moderate mean scores, namely, Syllabus Boundness $(\mathrm{m}=4.6635$, std $=0.81178)$, and Fear of Failure $(\mathrm{m}=4.5230$, std $=$ $0.89628)$. Unrelated Memorising $(m=4.2206$, std $=0.91140)$ and Lack of Purpose $(m=$ 3.8615$, std $=1.086)$.

\section{Research objective 2: an analysis on the differences between approaches to learning and gender}

Table 3: Independent t-test result for approaches to learning and gender

\begin{tabular}{lllll}
\hline Approaches to learning & mean & t-value & Sig value \\
\hline Deep & male & 5.2104 & 1.479 & 0.140 \\
& female & 5.0181 & & \\
Surface & male & 4.7208 & 3.097 & $0.02^{*}$ \\
& & & & \\
& female & 4.2886 & & \\
\multirow{2}{*}{ Strategic } & male & 5.1799 & 0.348 & 0.728 \\
& female & 5.1301 & & \\
\hline
\end{tabular}

Based on the independent t-test shown in table 3, there were no significant differences between deep and approaches and strategic approaches on gender where, $t=1.470$, $p=0.140$ and $t=0.348, p=0.728$, respectively. However, the result shows that there is a significant difference between surface approaches and gender, where $t=3.097, p=0.02$ ). This findings indicated that men (mean $=4.7208$ ) used more surface approaches than the women (mean $=4.2886$ ). This study contrast with the study done by (Severiens and Dam (1994) where men showed more inclined to deep approach to learning and women more to surface or reproducing approach to learning.

Research objective 3: An analysis on the relationships between CGPA and approaches to learning. 
Table 4: Correlation matrix analysis of academic achievement, deep, strategic and surface approaches to learning $(n=255)$

\begin{tabular}{llllll}
\hline Variables & 1 & 2 & 3 & 4 \\
\hline 1. & Academic achievement & 1.00 & & & \\
2. & Deep approach & .169 & 1.00 & & \\
3. & Strategic approach & .153 & .894 & 1.00 & \\
4. & Surface approach & .094 & .297 & .315 & 1.00 \\
\hline
\end{tabular}

Table 4 presents correlation matrix between trainee teachers' learning approaches on academic achievement. The finding reveals that that is a significant relationship between deep approach and strategic approach on academic achievement where $r=.169, p=0.00$ and $r=0.153, p=0.018$, respectively. However, the result shows that there is no significant relationship between surface approach and academic achievement, where $r=0.94, p=0.152$. In the other word, surface approach does not influence academic achievement of the trainee teachers. However, deep and strategic approaches do influence academic achievement.

\section{Research objective 4: An analysis on the contribution of approaches to learning towards the variance of academic achievement}

Table 5: Multiple Regression Analysis on academic achievement

\begin{tabular}{lllll}
\hline variables & Un standardized & Standardized & $t$-value & Sig \\
\hline constant & 2.876 & & 18.777 & 0.00 \\
Seeking meaning & 0.056 & 0.160 & 1.439 & 0.152 \\
Relating ideas & 0.012 & 0.031 & 0.280 & 0.780 \\
Use of evidence & -.081 & -0.224 & -1.733 & 0.085 \\
Interest in ideas & 0.013 & 0.038 & 0.326 & 0.745 \\
Organized studying & -0.001 & -0.002 & -0.014 & 0.989 \\
Time management & -0.045 & -0.137 & -1.172 & 0.242 \\
Alertness to assessment & -0.066 & 0.042 & -1.572 & 0.118 \\
demand & & & & \\
achieving & 0.119 & 0.338 & 2.497 & $0.013^{\text {** }}$ \\
Monitoring effectiveness & 0.060 & 0.171 & 1.402 & 0.162 \\
Lack of purpose & 0.029 & 0.114 & 1.215 & 0.226 \\
Unrelated memorising & -0.090 & -0.295 & -2.969 & $0.003^{\text {** }}$ \\
Syllabus boundness & -0.003 & -0.009 & -0.085 & 0.932 \\
Fear of failure & 0.084 & 0.274 & 3.007 & $\mathbf{0 . 0 0 3}^{\text {** }}$ \\
\hline
\end{tabular}

F-statistic $=2.972$, sig. $<0.01, R^{2}=0.155$, Adjusted $R^{2}=0.103$

Based on multiple regression analysis, as shown in table 5, the finding reveals that out of 13 sub scales of the approaches to learning, only three predictors were found to be significance, namely achieving, unrelated memorising and fear failure with their respective t and $p$ values $(t=2.497 p=0.013, t=-2.969, p=0.03, t=3.007, p=0.003$. The total amount of variance of the criterion variable that was predictable from the three predictors was $15.5 \%$, and the adjusted R square change of $10.3 \%$. Hence, since the adjusted R square could give a better estimation of the true population value, the contribution of the predictor variables 
towards the variance in the criterion variable in this study was reported based on the adjusted R-square value. Therefore, the overall regression model was successful in explaining approximately $10.3 \%$ of the adjusted variance in academic achievement.

The findings of this study have several practical implications for educators and head of the organziations. Firstly, the findings of this study have contributed to a better perceptive of the relationship between students' learning approaches and academic achievement. Using the right learning approach is essential in determining the student's learning outcomes. As the findings suggest that less usage of surface approach resulting in higher level of academic achievement, students need to reduce the use of unrelated memorising and syllabus boundness. They need to have a purpose and the right intention in their studies for their professional development and lifelong learning. Therefore, to help students to employ the right approach to learning, it is suggested that management of the institution to organise workshops or seminars to teach awareness to the students on the different approaches that they can utilize in their learning. It is also important that the students are aware that when they reproduce materials or memorise facts instead of understanding them, it can have a negative affect towards their CGPA result. Secondly, teachers or educators also need to be aware that their teaching practices and the course design as it can affect the intention of the students. Teachers need to discourage the use of surface approach and design course that require the students to think critically, seek meaning, to understand their studies material and to be able to relate ideas with prior knowledge or their own experiences. Accordingly, educators must provide a learning environment where students develop a strong personal interest this is because Warburton (2003) argues that a first step in reaching a deep learning is a high level of student commitment with the learning subject so that students are motivated to understand. Thus, by promoting or inducing deep approach to learning, it is hope that surface approach to learning can be reduced.

\subsection{Conclusion}

This study intends to examine approaches to learning among the trainee teachers of UiTM, Shah Alam. The finding reveals that majority of the respondents were inclined towards using deep and strategic approaches to learning. In this context one could relate that students' way of learning varies even though they were in the same program or courses. Marton (1976) claims that students may adopt one approach rather than another, depending upon their conceptions of learning and their conceptions of themselves as learner. Nevertheless, Richardson (2000) asserts the choice of one approach to studying depend upon the content, the context, and the demands of particular tasks. Thus, interestingly the finding suggests that the respondents were inclined into looking for meaning in what they study rather than memories it. At the same times, in the process of learning they also have the tendencies to get a good mark on a unit by organizing their time well, by finding the right conditions for studying and by putting consistent effort into their study. 
To conclude, teachers and educators generally teach the way they were taught. Teachers have the tendencies to teach by the usual traditional means i.e. giving lectures. Teachers, or similarly, lecturers and educators in higher institutions, need to know beyond their subject (Grove-White, 2003). In other words, educators need to know the ways a subject is understood, misunderstood, and what actually represents one's understanding and experience in relating to the subject (Grove-White, 2003). Thus, knowledge on how students learned and the strategies or the approaches they ulitized would bring about a greater impact on the learning process, engagement and outcome. In other words, what this implies is that, educators must challenge themselves to understand more about the learners, in particular how these students learned and the approaches they used when approaching a task. It has come to a point where the educator in higher institutions must bridge the gap between the students and themselves by understanding more about the learners so as to promote better learning outcome and performance.

\section{References}

Aaron, S. \& Skakun, E. (1999). Correlation of students' characteristics with their learning styles as they begin medical school. Academic Medicine. Vol 74, No 3.

Ali, W. G. M., \& Sebai, N. A. M. E. (2010). Effect of problem-based learning on nursing students' approaches to learning and their self directed learning abilities. International Journal of Academic Research, 2(4), 188-195.

Allie, S., Armien, M.N., Bennie, K., Burgoyne, N., Case, J., and Craig, T., et al. (2007). Learning as acquiring a discursive identity through participation in a community: A theoretical position on improving student learning in tertiary science and engineering programmes. Unpublished manuscript, Centre for Research in Engineering Education, Cape Town, South Africa, http://www.cree.uct.ac.za.

Arquero Montano, J.L., Gonzalez, J.M.G., Hassall, T., Joyce, J., Germanou, E. ～\& Asonitou, S. 2010. 'The approaches to learning of Europea accounting students', EuroMed Journal of Business, 5(3): 345-362

Baeten, M., Kyndt, E., Struyven, K., \& Dochy, F. (2010). Using student-centred learning environments to stimulate deep approaches to learning: factors encouraging or discouraging their effectiveness. Press Educational Research Review 2010.

Baeten, M., Dochy, F., \& Struyven, K. (2008). Students' approaches to learning and assessment preferences in a portfolio-based learning environment. Instructional Science, 36, 359-374.

Baeten, M. (2008). The effects of contrasting learning environments on students' approaches to learning and students' learning outcomes, taking into account students' course experiences and student characteristics. (Doctoral proposal). Faculty of psychology and educational sciences, Centre for Research on Teaching and Training. Retrieved from: ppw.kuleuven.be/cscap/doctoral\%20proposal\%20Baeten.doc

Ballantine, J. A., Duff, A., \& McCourt Larres, P. (2008). Accounting and business students' approaches to learning: A Iongitudinal study. Journal of Accounting Education, 26(4), 188-201. Retrieved from: http://www.sciencedirect.com/science/article/pii/S0748575109000062 
Biggs, J. B., Kember, D., \& Leung, D. (2001). The revised two-factor study process questionnaire: R-SPQ-2F. British Journal of Educational Psychology, 71(1), 133-149.

Birenbaum, M. (2007). Assessment and instruction preferences and their relationship with test anxiety and learning strategies. Higher Education, 53(6), 749-768. Retrieved from http://www.springerlink.com/content/v20lp5w5141r0612/

Bradford, K. (2001). Deep and Surface Approaches to Learning and the Strategic Approach to Study in Higher Education; Based on Phenomenographic Research. Retrieved on June 8, 2011 from http://www.arasite.org/guestkb.htm

Biggs, J.B. (1987). Student approaches to learning and studying. Melbourne, Australia: Australian Council for Educational Research

Cassidy, S. (2006). Learning style and student self-assessment skill. Education and Training, 48 (2-3), 170-177.

Cano, J. (1999). The relationship between learning style, academic major, and academic performance of college students. Journal of Agricultural Education, 40(1), 30-37.

Cano, F. (2007). Approaches to learning and study orchestrations in high school students. European Journal of Psychology of Education, 22(2), 131 - 151.

Cano, F. (2005). Epistemological beliefs and approaches to learning: Their change through secondary school and their influence on academic performance. British Journal of Educational Psychology, 75, 203-221.

Chan, K. (2003) Hong Kong teacher education students' epistemological beliefs and approaches to learning,

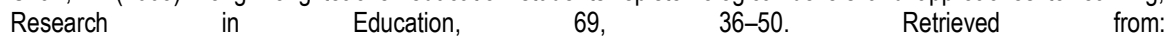
http://www.manchesteruniversitypress.co.uk/uploads/docs/690036.pdf

Chan, K. W. (2007). Hong Kong Teacher Education, Students Epistemological Beliefs and their Relations with Conceptions of Learning and Learning Strategies. The Asia Pacific Education Researcher. 16, 199 - 214. Retrieved from: http://www.dlsu.edu.ph/research/journals/taper/pdf/200712/chan.pdf

Chang, Y. C. (2010). Students' perceptions of teaching styles and use of learning strategies. Masters Theses. University of Tennessee, Available online at http://trace.tennessee.edu/cgi/viewcontent.cgi?article=1835\&context=utk_gradthes. Retrieved on 18 th July 2011.

Dale, C. and McCarthy, P. (2006) I like your style: The learning approaches of leisure, tourism and hospitality students studying generic modules, Journal of Hospitality, Leisure, Sport and Tourism Education, 5 (2), 48-58. Retrieved from: http://business.heacademy.ac.uk/assets/hlst/documents/johlste/vol5no2/0116.pdf

Entwistle, N., and McCune, V. (2004). The conceptual bases of study strategy inventories. Educational Psychology Review, 16(4): 325-345. Retrieved from: http://www.springerlink.com/content/27747602358j724/

Entwistle, N. J., \& Smith, C. A. (2002). Personal understanding and target understanding: mapping influences on the outcomes of learning. British Journal of Educational Psychology, 72, 321-342.

Entwistle, N. (2000). Promoting deep learning through teaching and assessment: conceptual frameworks and educational contexts [online]. (Paper presented at TLRP Conference, Leicester, November 2000). [Accessed 8 June 2011]. 
Entwistle, N., Tait, H., \& McCune, V. (2000). Patterns of response to an approaches to studying inventory across contrasting groups and contexts. European Journal of Psychology of Education, 15(1), 33-48. Retrieved from http://www.springerlink.com/content/v803p0pu07h27046/

Entwistle, N. J. (1991). Approaches to learning and perceptions of the learning environment. Higher Education 22: $201-204$

Floyd, K. S., Harrington, S. J., \& Santiago, J. (2009). The effect of student engagement and perceived course value on deep and surface learning strategies. Informing Science: The International Journal of Emerging Transdiscipline, 12, 181-190. Retrieved on June 8, 2011 from http://www.arasite.org/guestkb.htm

Fraenkel, J. R., \& Wallen, N. E., (2008). How to design and evaluate research in education: $7^{\text {th }}$ Edition. McGraw-Hill International Edition. New York.

Garton, B. L., Spain, J. N., Lamberson, W. R., \& Spiers, D. E. (1999). Learning styles, teaching performance, and student achievement: A relationship study. Journal of Agricultural Education, 40(3), 11-20.

Gijbels, D., \& Dochy, F. (2006). Students' assessment preferences and approaches to learning: Can formative assessment make a difference? Educational Studies, 32(4), 399-409. Retrieved from: https://perswww.kuleuven.be/ u0015308/Publications/CEDS_A_184968_O.pdf

Gijbels, D., van de Watering, G., Dochy, F. \& van den Bossche, P. (2005). The relationship between students' approaches to learning and learning outcomes, European Journal of Psychology of Education, 20(4), 327-341. Retrieved from: https://perswww.kuleuven.be/ u0015308/Publications/EJPE2005.pdf

Gordon, C. \& Debus, R. (2002) Developing deep learning approaches and personal teaching efficacy within a preservice teacher education context, British Journal of Educational Psychology, 22, 483-511. Retrieved from http://www.numyspace.co.uk/ unn_evdw3/skills/2010/papers/deep1.pdf

Government of Malaysia, (1997). The Malaysian Smart School Conceptual Blueprint: An MSC Flagship Application. Retrieved from http://www.mscmalaysia.my/codenavia/portals/msc/images/pdf/ss-blueprint.pdf

Guildford, J. 1956. Fundamental statistics in psychology and education. New York: McGraw Hill.

Hassall, T. \& Joyce, J. 2001. 'Approaches to learning of management accounting students', Education and Training, 43(3): $145-152$

Hanin Naziha Hasnor, Zaiton Ahmad and Norshidah Nordin (2013) The Relationship Between Learning Approaches And AcademicAchievement Among Intec Students, UiTM Shah Alam. Procedia - Social and Behavioral Sciences $90(178-186$

Heikkilä, A. (2011). University students' approaches to learning, self-regulation, and cognitive and attributional strategies: connections with well-being and academic success reference. (Doctoral dissertation). Retrieved from https://helda.helsinki.fi/bitstream/handle/10138/25859/universi.pdf?sequence=1

Kaur, S., \& Thiyagarajah, R. (1999). The English reading habit of ELLS students in University Science Malaysia. Available at: http://ultibase.eu.rmit.edu.au/Articles/may00/thiyag1.pdf

Kyndt, E. (2011). Investigating students' approaches to learning. (Doctoral dissertation). Retrieved from https://lirias.kuleuven.be/bitstream/123456789/307055/1/Doctoraat+Eva+Kyndt+(2011).pdf 
Lietz, P. \& Matthews, B. (2006). Are values more important than learning approaches? Factors influencing student performance at an international university. Paper presented at the AARE 2006 Conference, Australia: Adelaide. Available online at http://www.aare.edu.au/06pap/lie06070.pdf. Retrieved on 20th July 2011.

Mahyuddin, R., Elias, H., Cheong, L. S., Muhamad, M. F., Noordin, N., \& Abdullah, M. C. (2006). The relationship between students' self-efficacy and their English language achievement. Jurnal Pendidik dan Pendidikan, 21: 6171

March, M. L. (2010). Epistemological beliefs and approaches to learning: Influence on academic performance in higher education. (Doctoral dissertation). Capella University, Minneapolis State, MN.

Minbashian, A., Huon, G.F., \& Bird, K.D. (2004). Approaches to studying and academic performance in short-essay exams. Higher Education, 47, 161-176.

Morgan, A. (1993) Improving Your Students' Learning. London and Philadelphia: Kogan Page.

Naderi, H., Abdullah, R., Aizan, H. T., Sharir, J., \& Kumar, V. (2009). Creativity, age and gender as predictors of academic achievement among undergraduate students. Journal of American Science 5(5): 101-112.

Offir, B., Lev, Y., \& Bezalel, R. (2008). Surface and deep learning processes in distance education: Synchronous versus asynchronous systems. Computers and Education 51: 1172 - 1183. www.elsevier.com/locate/compedu.

Oxford, R. (1989). The role of styles and strategies in second language learning. ERIC Digest. Washington, DC: ERIC/CLL. Retrieved from: http://www.ericdigests.org/pre-9214/styles.htm 